\title{
Sensibly and appropriately the judge considered... A corpus-based study of sentence adverbs in judicial language*
}

\author{
Gianluca Pontrandolfo (Trieste)
}

\begin{abstract}
The paper presents a contrastive corpus-assisted discourse study of sentence adverbs in Italian, English and Spanish judicial discourse.

The hypothesis guiding the study is that, although judges' attitude is supposed to be impartial, as they represent the so-called "bouche de la loi", their opinion is present in the texts and sentence adverbs are one of the pragmatic vehicles used to express their stance.

The corpus used for the analysis is a trilingual subcorpus of COSPE (Pontrandolfo 2016) that has been POS-tagged (194,000 tokens for each language). The focus has then been placed exclusively on adverbs ending in -mente and -ly for being those that more than others contribute to express evaluative nuances in judicial discourse.

Results demonstrate that quantitatively adverbs in -mente/-ly do not account for a significant percentage, which is in line with Biber et al.'s (1999) findings in other registers (conversation, academic prose). However, qualitatively and discursively, these adverbs play a pivotal role at a pragmatic level, since they contribute to judicial argumentation (cf., among others, Mazzi 2014).
\end{abstract}

\footnotetext{
* This paper is partially framed within the project entitled Discurso jurídico y claridad comunicativa. Análisis contrastivo de sentencias españolas y de sentencias en español del Tribunal de justicia de la Unión Europea 'Legal discourse and clarity. Comparative analysis of Spanish judgments and judgments written in Spanish from the Court of justice of the European Union' (Referencia FFI2015-70332-P), financed by the Spanish Ministerio de Economía y Competitividad and FEDER funds (Leading Researcher: Estrella Montolío Durán, Universitat de Barcelona).
} 


\section{Introduction: the case against sentence adverbs in legal writing}

To most lawyers and legal experts sentence adverbs - that is to say, adverbs qualifying an entire statement rather than a single word in the sentence ${ }^{1}$ - represent linguistic elements that need to be "scrubbed" from legal writing for being pitfalls. ${ }^{2}$ Garner's comment is particularly emblematic in this respect:

Improvising sentence adverbs from traditional adverbs like 'hopefully' (= in a hopeful manner) and 'thankfully' (= in a thankful manner) is objectionable to many stylists but seems to be on the rise. E.g. 'Explanatorily' [read by way of explanation], these consolidated causes were positioned as the ordinary and uncomplicated condemnation case. O' Neil Corp vs. Perry Gas Transmission, Inc., 648 S.W. 2d, 335, 341 (Tex. App. - Amarillo 1983).

Avoid newfangled sentence adverbs of this kind. And in formal prose, even those like 'hopefully' and 'thankfully' shouldn't appear. Though increasingly common, they have a tarnished history.

Because sentence adverbs reveal the writer's own thoughts and biases, writers often overuse them in argumentation - but danger lurks in words such as 'clearly', 'obviously', 'undoubtedly', and 'indisputably'.

(Garner 2009: 734)

The "danger" lying in the use of those adverbs is known in the literature as well as in famous judicial decisions, like United States v. Yermian, in which the Supreme Court was asked to determine the scope of two sentence adverbs used in Section 1001 of the United States Criminal Code.

[w] hoever, in any matter within the jurisdiction of any department or agency of the United States knowingly and willfully [...] makes any false, fictitious or fraudulent statements [...] shall be fined.

(Title 18 U.S.C.C. § 1001, emphasis added; cited in Solan 1993: 67-73)

The linguistic issue in the case was whether the underlined portion of the statute fell within the scope of the two sentence adverbs knowingly and willfully. The debate among the justices developed into an argument about the linguistic consequences of the appearance of the emphasised portion of the statute. Particularly relevant was Justice Rehnquist's dissenting opinion, according to whom:

(T)he Court's reasoning here amounts to little more than simply pointing to the ambiguous phrases and proclaiming them clear. In my view, it is quite impossible to tell which phrases the term 'knowingly and willfully' modify, and the magic wand of ipse dixit does nothing to resolve that ambiguity

(Solan 1993: 70)

\footnotetext{
${ }^{1}$ Sentence adverbs qualify an entire statement rather than a single word in the sentence. A sentence adverb does not resolve itself into the form in a__ manner, as most adverbs do. Thus, in Happily, the bill did not go beyond the committee, the introductory adverb happily conveys the writer's opinion on the message being imparted.

The following words are among the most frequent sentence adverbs ending in -ly: accordingly, admittedly, apparently, arguably, certainly, concededly, consequently, curiously, fortunately, importantly, interestingly, ironically, legally, logically, mercifully, naturally, oddly, paradoxically, regrettably, sadly, strangely, theoretically (Garner 2009: 734).

2 See, as a way of example:

Salzwedel $(2012,2013)$,

Garner's Usage Tip of the Day: Sentence Adverbs. http://www.lawprose.org/garners-usage-tip-of-the-daysentence-adverbs/_[last accessed on 08/10/2018]
} 
Gianluca Pontrandolfo: A corpus-based study of sentence adverbs in judicial language

The impossibility to interpret correctly the sentence, in Justice Rehnquist's view, confirms the "danger that lurks" in using sentence adverbs and thus the advice of avoiding them in legal prose. In fact, due to their argumentative strength, sentence adverbs are used in judges' opinions as important pragmatic vehicles of their stance.

This paper aims at investigating, from a quantitative and qualitative point of view, the role of sentence adverbs in three different judicial settings: Italy, England and Wales, and Spain.

\section{Sentence adverbs in general and legal language}

Sentence adverbs have been analysed and classified in language for general purposes (LGP) in most of the existing grammar handbooks.

Table 1 summarises the classification proposed in three reference handbooks: the Grande Grammatica Italiana di Consultazione (GGIC 2001), the Longman Grammar of Spoken and Written English (LGSWE 1999), the Gramática Descriptiva de la Lengua Española (GDLE 1999) and the Gramática de Referencia de Español para Italófonos (GREIT 2013).

Reviewing the classical grammar handbooks has been a preliminary, fundamental step to reach a common, contrastive-based classification of sentence adverbs (presented in Table 2).

A quick glance at Table 1 shows the problems of classification lying in the three languages where some categories overlap and others not (cf. also Ramat/Ricca 1998).

\begin{tabular}{|c|c|c|}
\hline IT & $\mathbf{E N}$ & ES \\
\hline $\begin{array}{c}\text { AVVERBI(ALI) DI } \\
\text { FRASE }\end{array}$ & STANCE ADVERBIALS & $\begin{array}{l}\text { ADVERBIOS } \\
\text { ORACIONALES }\end{array}$ \\
\hline (GGIC) & (LGSWE) & (GREIT) / (GDLE) \\
\hline $\begin{array}{l}\text { MODALI (probabilmente, } \\
\text { presumibilmente, certa- } \\
\text { mente, verosimilmente, } \\
\text { paradossalmente, etc.) }\end{array}$ & 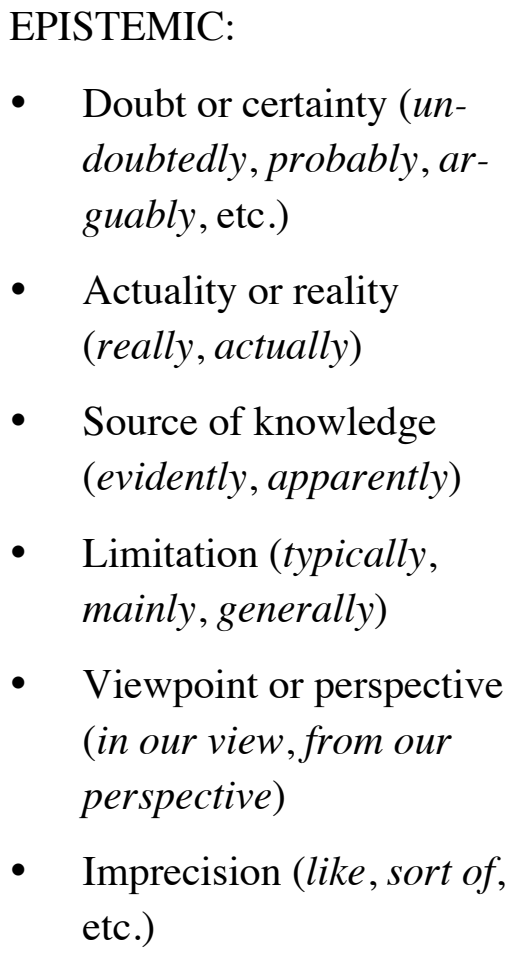 & $\begin{array}{l}\text { DE ENUNCIACIÓN } \\
\text { (francamente, sinceramente, } \\
\text { categóricamente, etc.) }\end{array}$ \\
\hline
\end{tabular}




\begin{tabular}{|c|c|c|}
\hline $\begin{array}{l}\text { VALUTATIVI (sfortuna- } \\
\text { tamente, stranamente, in- } \\
\text { comprensibilmente) }\end{array}$ & $\begin{array}{l}\text { ATTITUDINAL (unfortu- } \\
\text { nately, hopefully, sensibly, } \\
\text { etc.) }\end{array}$ & $\begin{array}{l}\text { DE TÓPICO } \\
\text { (económicamente, } \\
\text { lingüísticamente, etc.) }\end{array}$ \\
\hline $\begin{array}{l}\text { DI ACCADIMENTO o } \\
\text { EVENTO (improvvisamen- } \\
\text { te, inaspettatamente, etc.) }\end{array}$ & $\begin{array}{l}\text { STYLE (frankly, honestly, } \\
\text { truthfully) }\end{array}$ & $\begin{array}{l}\text { DE ENUNCIADO: } \\
\text { - } \quad \text { evaluativos } \\
\text { (afortunadamente, } \\
\text { felizmente, por suerte) } \\
\text { - } \quad \text { modales (probablemente, } \\
\text { quizás, necesariamente) } \\
\text { - } \quad \text { evidenciales (evidentemente, } \\
\text { indudablemente, } \\
\text { naturalmente) }\end{array}$ \\
\hline $\begin{array}{l}\text { DI INQUADRAMENTO } \\
\text { (solitamente, generalmen- } \\
\text { te, abitualmente, politica- } \\
\text { mente, economicamente, } \\
\text { etc.) }\end{array}$ & & \\
\hline \multicolumn{3}{|l|}{$\begin{array}{l}\text { DI ATTO LINGUISTICO } \\
\text { (francamente, personal- } \\
\text { mente, approssimativamen- } \\
\text { te, etc.) }\end{array}$} \\
\hline $\begin{array}{l}\text { DI SOGGETTO (intelli- } \\
\text { gentemente, saggiamente, } \\
\text { correttamente, etc.) }\end{array}$ & & \\
\hline
\end{tabular}

Table 1: Sentence adverbs' classification in Italian, English and Spanish grammar handbooks

As far as legal language is concerned, sentence adverbs have not been studied extensively and consistently, notwithstanding the widespread recognition of their presence in judicial discourse.

A review of the studies conducted so far has underlined the existence of few studies on legal adverbs, but not specifically on sentence adverbs.

As far as Italian is concerned, one of the few pieces of research carried out on adverbs in judicial language is the paper by Rovere (2000) who focuses on a different type of adverbs (instrumental ones) that play an important role in Italian judicial language (ex. con decreto, con ricorso, etc.).

As far as English studies are concerned, there are few studies that have dealt with stance adverbs. Remarkable exceptions are two papers by Mazzi, who has studied adverbials of stance in equity judges' argumentation (2008), as well as attitudinal qualification in English judicial discourse (2015). 
Gianluca Pontrandolfo: A corpus-based study of sentence adverbs in judicial language

Finally, adverbs in -mente have been scarcely investigated in Spanish by Landone (2013a, 2013b) who has focused on the role of these adverbs in administrative discourse.

In order to conduct an empirical investigation of sentence adverbs in judicial language, it has been necessary to consider the same categories for the three languages. The result is shown in Table 2, which has been the methodological point of the departure for the empirical analysis.

\begin{tabular}{|l|l|l|l|}
\hline & IT & EN & ES \\
\hline MODAL & modali [GGIC] & $\begin{array}{l}\text { epistemic expressing } \\
\text { doubt or certainty } \\
\text { [LGSWE] }\end{array}$ & $\begin{array}{l}\text { de enunciado: moda- } \\
\text { les [GREIT]/ } \\
\text { relacionados con la } \\
\text { modalidad [GDLE] }\end{array}$ \\
\hline
\end{tabular}

IT: probabilmente, presumibilmente, certamente, verosímilmente, etc.

EN: undoubtedly, probably, arguably, etc.

ES: seguramente, probablemente, posiblemente, etc.

\begin{tabular}{|l|l|l|l|}
\hline EVALUATIVE & valutativi [GGIC] & attitudinal [LGSWE] & $\begin{array}{l}\text { de enunciado: evalua- } \\
\text { tivos [GREIT] } \\
\text { [GDLE] }\end{array}$ \\
\hline
\end{tabular}

IT: sfortunatamente, stranamente, incomprensibilmente, etc.

EN: unfortunately, hopefully, sensibly, etc.

ES: absurdamente, afortunadamente, felizmente, etc.

\begin{tabular}{|l|l|l|l|}
\hline DOMAIN & $\begin{array}{l}\text { di inquadramento } \\
\text { [GGIC] }\end{array}$ & $\begin{array}{l}\text { epistemic: viewpoint } \\
\text { or perspective } \\
\text { [LGSWE] }\end{array}$ & $\begin{array}{l}\text { nocionales o "de pun- } \\
\text { to de vista" [GDLE] } \\
\text { de tópico [GREIT] }\end{array}$ \\
\hline
\end{tabular}

IT: politicamente, economicamente, etc.

EN: theoretically, legally, politically, etc.

ES: teóricamente, filosóficamente, políticamente, etc.

\begin{tabular}{|l|l|l|l|}
\hline $\begin{array}{l}\text { SUBJECT- } \\
\text { oriented }\end{array}$ & di soggetto [GGIC] & $\begin{array}{l}\text { attitude adverbial } \\
\text { conveying evalua- } \\
\text { tion [LGSWE] }\end{array}$ & $\begin{array}{l}\text { evaluativos de la ac- } \\
\text { tuación del sujeto } \\
\text { [GDLE] }\end{array}$ \\
\hline attitudinal) & [Griter's
\end{tabular}

IT: intelligentemente, saggiamente, correttamente, etc.

EN: conveniently, wisely, sensibly, rightly, etc.

ES: inteligentemente, hábilmente, sabiamente, etc. 


\begin{tabular}{|c|c|c|c|}
\hline SPEECH ACT & $\begin{array}{l}\text { di atto linguistico } \\
\text { [GGIC] }\end{array}$ & $\begin{array}{l}\text { style adverbs } \\
\text { [LGSWE] }\end{array}$ & $\begin{array}{l}\text { de enunciación: } \\
\text { orientados hacia el } \\
\text { emisor o el receptor } \\
\text { [GDLE] }\end{array}$ \\
\hline \multicolumn{4}{|c|}{ IT: francamente, personalmente, approssimativamente, etc. } \\
\hline \multicolumn{4}{|c|}{ EN: frankly, honestly, truthfully, etc. } \\
\hline \multicolumn{4}{|c|}{ ES: francamente, sinceramente, categóricamente, etc. } \\
\hline
\end{tabular}

Table 2: Contrastive classification of sentence adverbs

\section{The case study}

The objective of the study has been to carry out a quali-quantitative investigation of sentence adverbs - following the contrastive classification provided in Table 2 - in judges' discourse with a view to get insights into judicial argumentation. The method applied for the analysis falls within the so-called Corpus-Assisted Discourse Study (Partington et al. 2013) in which the corpus is a test bed to investigate, more qualitatively, discursive features.

As far as the corpus used for the analysis is concerned, a POS-tagged subcorpus of COSPE (Pontrandolfo 2016), a collection of criminal judgments delivered by the Italian, English and Welsh, and Spanish Supreme Courts, has been used.

The composition of the subcorpus under scrutiny is described in Table 3.

\begin{tabular}{|l|l|l|l|}
\hline \multicolumn{1}{|c|}{ IT } & \multicolumn{1}{|c|}{ EN } & \multicolumn{1}{c|}{ ES } \\
\hline Txt & $\begin{array}{l}\text { 57 judgments (Corte } \\
\text { Suprema di Cassa- } \\
\text { zione, CSC) }\end{array}$ & $\begin{array}{l}\text { 18 judgments (House } \\
\text { of Lords, HL + Su- } \\
\text { preme Court, SC) }\end{array}$ & $\begin{array}{l}\text { 26 judgments (Tri- } \\
\text { bunal Supremo, TS) }\end{array}$ \\
\hline time span & $2005-2012$ & $2009-2012$ & $2005-2012$ \\
\hline tokens & $\mathbf{1 9 3 , 4 1 1}$ & $\mathbf{1 9 3 , 5 1 6}$ & $\mathbf{1 9 4 , 0 0 2}$ \\
\hline
\end{tabular}

Table 3: POS-tagged subcorpus of COSPE used for the analysis

The corpus has been tagged by means of TreeTagger ${ }^{3}$ and queried with both AntConc (Anthony 2014) and WordSmith Tools (Scott 2008).

Working with a POS-tagged corpus entails many advantages: first of all, it allows to save time while performing the queries, since it is possible to search directly the part of speech in question rather than single words or phrases; then, it can be of great use in comparing data related

\footnotetext{
3 TreeTagger - a part-of-speech tagger for many languages. http://www .cis.unimuenchen.de/ schmid/tools/TreeTagger/ [last accessed on 08/10/2018].
} 
Gianluca Pontrandolfo: A corpus-based study of sentence adverbs in judicial language

to parts of speech. Table 4, for example, shows the number of adverbs (ADV*/RB), adjectives $\left(\mathrm{ADJ} / \mathrm{JJ}^{*}\right)$, nouns $\left(\mathrm{NN}^{*}\right)$ and pronouns $\left(\mathrm{PP}^{*}\right)$ in the subcorpus used for the analysis. ${ }^{4}$

\begin{tabular}{|l|l|l|l|}
\hline & \multicolumn{1}{|c|}{ IT } & \multicolumn{1}{c|}{ EN } & \multicolumn{1}{c|}{ ES } \\
\hline $\mathrm{ADV}^{*} / \mathrm{RB}$ & $\mathbf{8 , 9 0 5}$ & $\mathbf{7 , 3 9 4}$ & $\mathbf{4 , 4 2 7}$ \\
\hline $\mathrm{ADJ} / \mathrm{JJ}^{*}$ & 17,522 & 14,286 & 13,797 \\
\hline $\mathrm{NN}^{*}$ & 57,793 & 43,195 & 54,653 \\
\hline $\mathrm{PP}^{*}$ & 1,483 & 6,719 & 3,048 \\
\hline
\end{tabular}

Table 4: Adverbs, adjectives, nouns and pronouns in COSPE's subcorpus

Apart from mere quantitative considerations about the frequency of each POS in the corpus, it is interesting to observe, as a way of example, that personal pronouns are much more frequent in English, ${ }^{5}$ which is in line with the personal style adopted by English judges in their opinions (Pontrandolfo 2016: 63-68).

The focus of this study has been placed on adverbs derived by suffixation - formed by suffixing -mente (in Italian and Spanish) and -ly (in English) to the base form of an adjective - because they often function as sentence adverbs. From a methodological point of view, searching for these adverbs with AntConc has been relatively straightforward, as can be seen in Figure 1 , although the identification of sentence adverbs has been carried out manually.

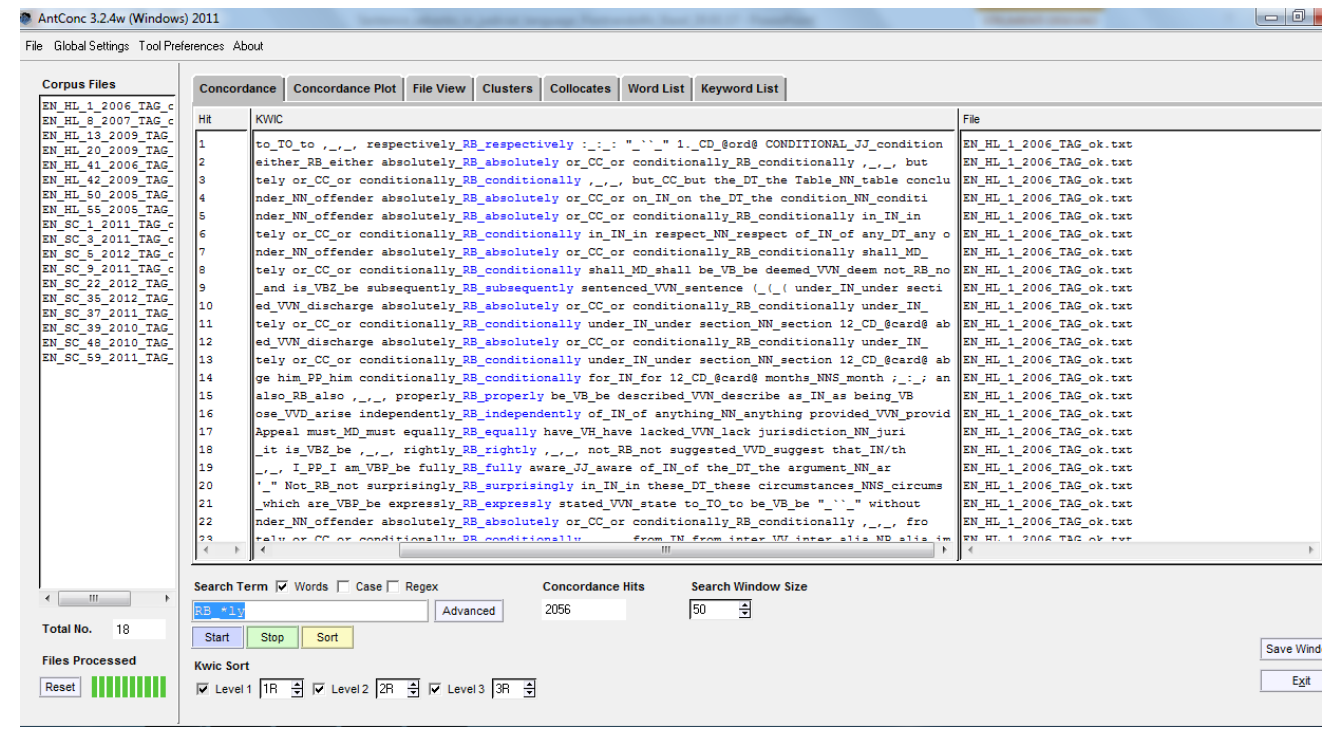

Figure 1: Querying adverbs ending in -ly in English $\left(\mathbf{R B}_{-} * 1 \mathbf{y}\right)$

The hypothesis guiding the research is that although judges are supposed to be impartial in their reasoning (they should represent the so-called "bouche de la loi"), their stance can be

\footnotetext{
${ }^{4}$ A margin of error should be taken into account when considering the automatic POS-tagging carried out by means of TreeTagger.

${ }^{5}$ Although English is a language in which the subject pronouns are compulsory (which may affect the high frequency of this category), the result is still interesting since English judges decide to personalise their judgments (using I think, $\boldsymbol{m y}$ view, etc.) deliberately avoiding the passive voice or the depersonalisation which characterise the civil law tradition (Italian and Spanish judgments).
} 
inferred in the texts they deliver and sentence adverbs are one of the means used to express their personal or collegial opinions.

In terms of expected results, considering the two different legal traditions (civil law for Italy and Spain, common law for England and Wales), overt evaluation is expected to be found with a higher percentage in English judgments compared to Italian and Spanish ones.

\section{$4 \quad$ Results}

Table 5 presents the quantitative results of the investigation. Compared to the total number of adverbs obtained with TreeTagger, but especially with the total number of adverbs ending in -mente/-ly, the number of sentence adverbs is low. They account for $5 \%$ of all adverbs in -mente in Italian ( $0.9 \%$ of all adverbs), $6 \%$ of all adverbs ending in -ly in the case of English (1.7\% of all adverbs) and $4 \%$ of all adverbs ending in -mente in the case of Spanish $(1.2 \%)$.

\begin{tabular}{|l|l|l|l|}
\hline & \multicolumn{1}{|c|}{ IT } & \multicolumn{1}{c|}{ EN } & \multicolumn{1}{c|}{ ES } \\
\hline adverbs & 8,905 & 7,394 & 4,427 \\
\hline *mente/-ly & 1,813 & 2,048 & 1,306 \\
\hline sentence adverbs & $\mathbf{8 9 [ 5 \% ]}$ & $\mathbf{1 2 4 [ 6 \% ]}$ & $\mathbf{5 3}[\mathbf{4} \%]$ \\
\hline
\end{tabular}

Table 5: Adverbs, adverbs ending in -mente/-ly and sentence adverbs in COSPE's subcorpus

These first quantitative results seem to confirm Biber et al.'s findings:

Stance adverbials are much less common than circumstance adverbials. ${ }^{6}$ In fact, most sentences in English do not contain stance adverbials. Rather, they are statements made without overt stance markers

(LGSWE 1999: 853)

The reason why the number of sentence adverbs decreases compared to the percentage of adverbs ending in -mente/-ly lies in the fact that most of the latter are found in collocations like adverbs + adjective/past participle or adverbs + verbs $^{7}$ which, although evaluative in their meanings, only refer to nouns and not to the whole sentence. Therefore, they have been excluded from the analysis.

Table 6 presents a breakdown of the results for each category: modal (MOD), evaluative (EVAL), domain (DOM), subject-oriented (SUB), speech-act (SPAC). The quantitative picture is then presented in Figure 2, which underlines the distribution of each category in the subcorpus.

\footnotetext{
6 "Circumstantial adverbs add information about the action or state described in the clause, answering questions such as How, When, Where, How much, To what extent, Why. They include both obligatory adverbials [...] and optional adverbials [...]" (ibd.: 763). Some examples: After intensive tests, they believe that AIDS [...]; He was now sitting on the sofa.

${ }^{7}$ Some examples: IT) Escludeva che $i$ fatti potessero essere diversamente qualificati come truffe [CSC_948_2009]; EN) The appellants candidly acknowledge that [...] [SC_9_2011]; ES) [...] indicios no debidamente fundados, [...] [TS_951_2007].
} 
Gianluca Pontrandolfo: A corpus-based study of sentence adverbs in judicial language

\begin{tabular}{|r|c|c|c|c|c|}
\hline & MOD & EVAL & DOM & SUB & SPAC \\
\hline IT & 34 & 15 & 6 & 20 & 14 \\
\hline & $38 \%$ & $17 \%$ & $7 \%$ & $22 \%$ & $16 \%$ \\
\hline EN & 60 & 29 & 19 & 11 & 5 \\
\hline & $48 \%$ & $23 \%$ & $15 \%$ & $9 \%$ & $5 \%$ \\
\hline & 31 & 8 & 8 & 2 & 4 \\
\hline & $58 \%$ & $15 \%$ & $15 \%$ & $4 \%$ & $8 \%$ \\
\hline
\end{tabular}

Table 6: Sentence adverbs in COSPE's subcorpus: breakdown

Sentence Adverbs in COSPE's subcorpus

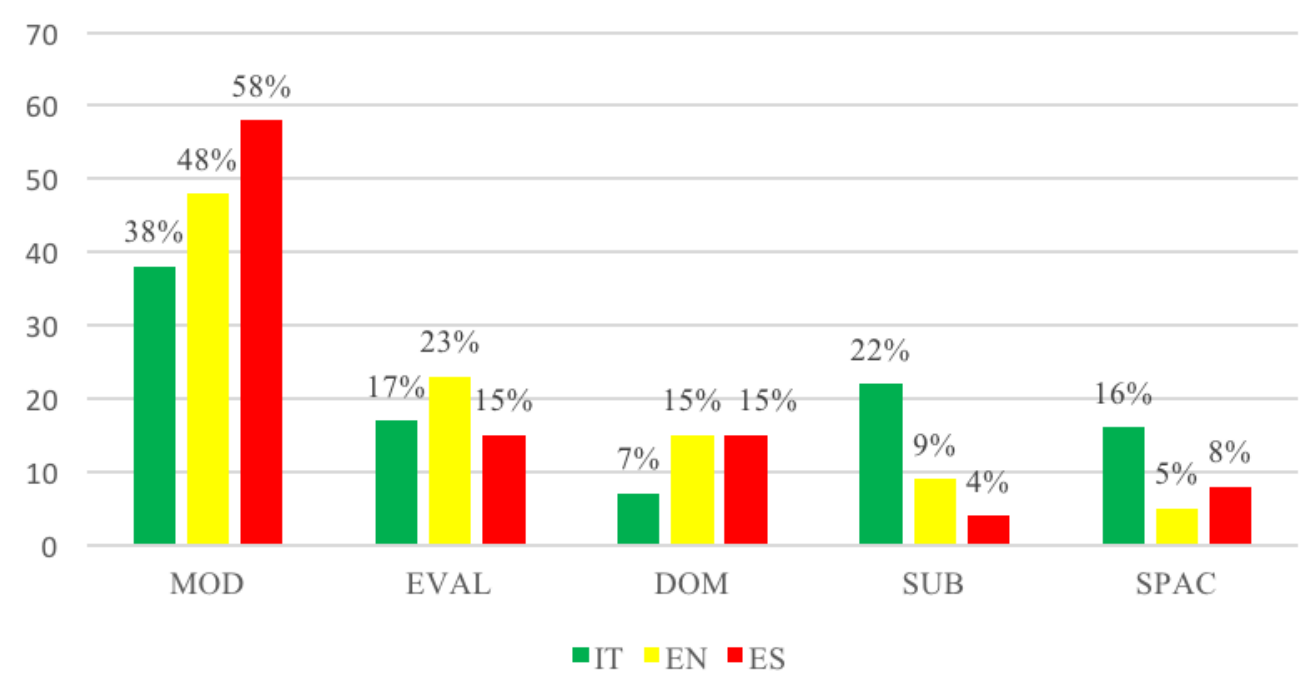

Figure 2: Sentence adverbs in COSPE's subcorpus

Modal adverbs are the most frequent category in the three subcorpora, followed by evaluative ones. Subject-oriented adverbs and speech-act are more frequent in Italian than in English and Spanish, whereas domain adverbs are more frequent in English and Spanish.

It is interesting to observe that the difference between Spanish and Italian subject-oriented sentence adverbs is quite remarkable ( $4 \%$ vs. $22 \%$ ), notwithstanding the fact that both cultures belong to the same legal tradition. The results of this small-case study show that Italian judges are more overt in expressing their stance, whereas the Spanish ones prefer to use modal sentence adverbs as a "safe" device not to engage in polemic dialogical interactions (cf. § 4.4).

The overall quantitative situation, shown in Figure 2, confirms a similar picture in which, apart from modal/epistemic, sentence adverbs are relatively scarce in judicial discourse. 
From a quali-quantitative point of view, it is worth stressing that the list of types ${ }^{8}$ (i. e. the list of unique adverbs) is quite limited (cf. Table 7) and there are many adverbs occurring only once (hapaxes ${ }^{9}$ ) (cf. Table 8).

\begin{tabular}{|l|c|c|c|}
\hline Sentence adverbs & IT & EN & ES \\
\hline types & 49 & 61 & 24 \\
\hline tokens & 89 & 124 & 53 \\
\hline TTR & 0.55 & 0.49 & 0.45 \\
\hline
\end{tabular}

Table 7: Types vs. tokens in COSPE's subcorpus

The type-token ratio ${ }^{10}$ seems to indicate that the Italian subcorpus is more varied compared to the English and the Spanish one where sentence adverbs tend to be repeated in the texts. ${ }^{11}$

\begin{tabular}{|l|l|l|l|l|l|}
\hline \multicolumn{1}{|c|}{ IT } & & \multicolumn{1}{c|}{ EN } & & \multicolumn{1}{c|}{ ES } & \\
\hline ovviamente & 10 & essentially & 7 & ciertamente & 11 \\
\hline certamente & 5 & obviously & 7 & realmente & 9 \\
\hline correttamente & 5 & certainly & 6 & lógicamente & 4 \\
\hline preliminarmente & 5 & importantly & 6 & concretamente & 3 \\
\hline diversamente & 4 & likely & 6 & obviamente & 3 \\
\hline evidentemente & 4 & plainly & 6 & claramente & 2 \\
\hline giustamente & 4 & clearly & 5 & efectivamente & 2 \\
\hline segnatamente & 4 & presumably & 5 & evidentemente & 2 \\
\hline erroneamente & 2 & surprisingly & 4 & abstractamente & 1 \\
\hline esattamente & 2 & understandably & 4 & categóricamente & 1 \\
\hline logicamente & 2 & inevitably & 3 & constitucionalmente & 1 \\
\hline pacificamente & 2 & rightly & 3 & erróneamente & 1 \\
\hline ragionevolmente & 2 & unlikely & 3 & incomprensiblemente & 1 \\
\hline rettamente & 2 & alternatively & 2 & jurisprudencialmente & 1 \\
\hline sostanzialmente & 2 & arguably & 2 & justamente & 1 \\
\hline verosimilmente & 2 & cumulatively & 2 & lamentablemente & 1 \\
\hline
\end{tabular}

\footnotetext{
8 "While the number of tokens in a corpus refers to the total number of words, the number of types refers to the total number of unique words" (Baker et al. 2006: 162).

9 "In corpus linguistics, a hapax is a word that occurs only once in a particular corpus" (Baker et al. 2006: 81).

10 "The number of types (unique words) in a text, divided by the number of tokens (total number of words) and expressed as a percentage. A high type/token ratio suggests that a text is lexically diverse, whereas a low type/token ratio suggests that there is a lot of repetition of lexical items in a file" (Baker et al. 2006: 162).

${ }^{11}$ However, this result might be biased by the higher number of judgments (57) contained in the Italian subcorpus compared to the other two subcorpora (18 and 26 respectively).
} 
Gianluca Pontrandolfo: A corpus-based study of sentence adverbs in judicial language

\begin{tabular}{|c|c|c|c|c|c|}
\hline amministrativamente & 1 & generally & 2 & modernamente & 1 \\
\hline chiaramente & 1 & legitimately & 2 & normalmente & 1 \\
\hline coerentemente & 1 & paradoxically & 2 & objetivamente & 1 \\
\hline conclusivamente & 1 & particularly & 2 & paulatinamente & 1 \\
\hline contraddittoriamente & 1 & realistically & 2 & precisamente & 1 \\
\hline effettivamente & 1 & typically & 2 & resumidamente & 1 \\
\hline emblematicamente & 1 & unquestionably & 2 & simplemente & 1 \\
\hline essenzialmente & 1 & usually & 2 & sintomáticamente & 1 \\
\hline fondamentalmente & 1 & absolutely & 1 & & \\
\hline formalmente & 1 & appropriately & 1 & & \\
\hline genericamente & 1 & commonly & 1 & & \\
\hline illegittimamente & 1 & comparatively & 1 & & \\
\hline immotivatamente & 1 & conversely & 1 & & \\
\hline incidentalmente & 1 & economically & 1 & & \\
\hline incolpevolmente & 1 & efficiently & 1 & & \\
\hline incongruamente & 1 & evidently & 1 & & \\
\hline indebitamente & 1 & implicitly & 1 & & \\
\hline indiscutibilmente & 1 & inappropriately & 1 & & \\
\hline legittimamente & 1 & incorrectly & 1 & & \\
\hline limitatamente & 1 & indisputably & 1 & & \\
\hline necessariamente & 1 & inferentially & 1 & & \\
\hline paradossalmente & 1 & inherently & 1 & & \\
\hline paradossalmente & 1 & initially & 1 & & \\
\hline personalmente & 1 & internationally & 1 & & \\
\hline precisamente & 1 & invariably & 1 & & \\
\hline primieramente & 1 & logically & 1 & & \\
\hline secondariamente & 1 & nationally & 1 & & \\
\hline semplicemente & 1 & naturally & 1 & & \\
\hline separatamente & 1 & oddly & 1 & & \\
\hline significativamente & 1 & ordinarily & 1 & & \\
\hline surrettiziamente & 1 & precisely & 1 & & \\
\hline
\end{tabular}




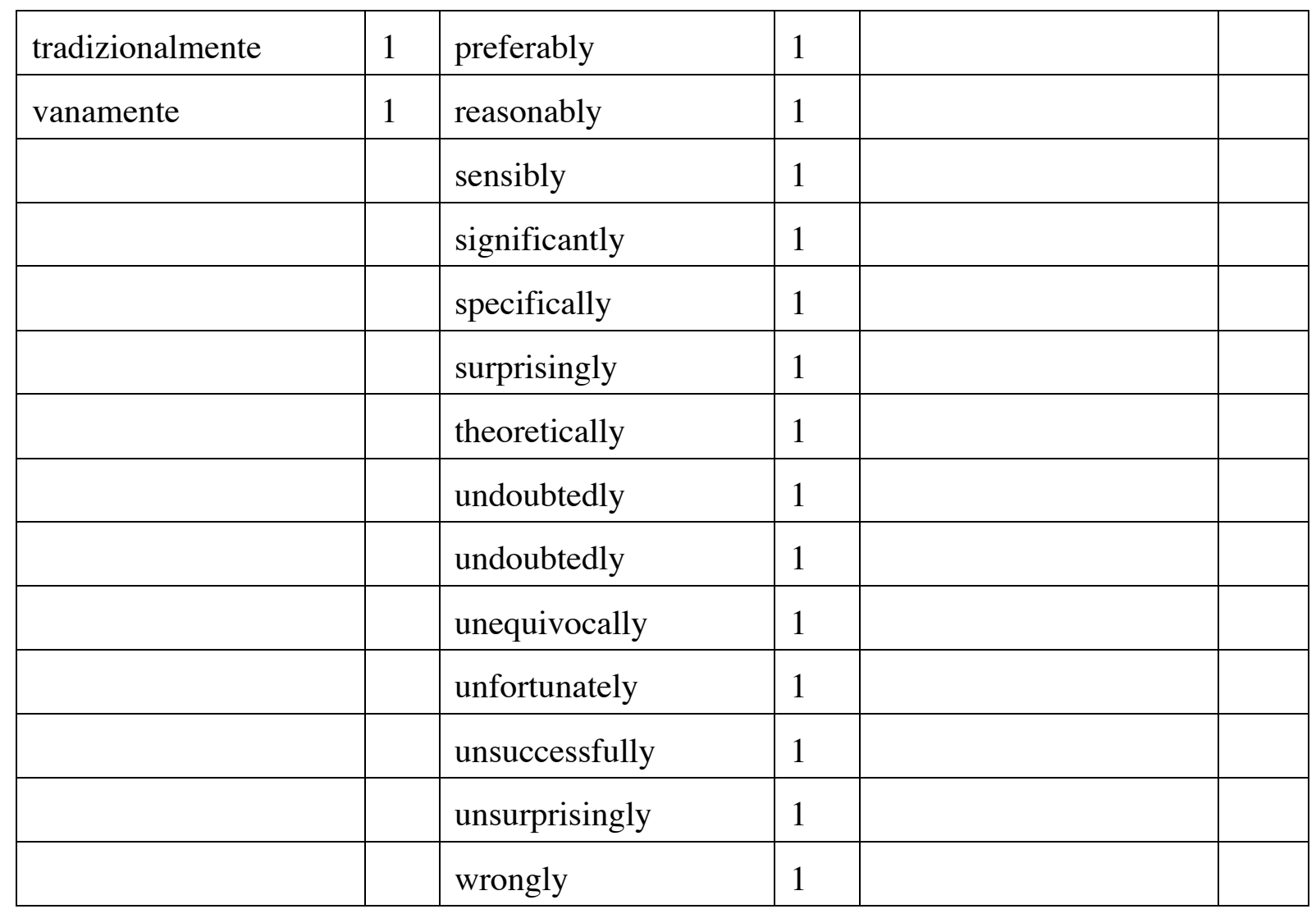

Table 8: Types of sentence adverbs in COSPE's subcorpus

\subsection{Modal}

Modal adverbials are the most frequent category of sentence adverbs found in the corpus. Most of them express doubt or certainty (undoubtedly, probably, arguably, etc.) or source of knowledge (evidently, apparently, etc.) and are used to show that a proposition is based on some evidence, without specifying the exact source, which is a feature of legal discourse (Pontrandolfo 2016: 133).

1. Non è sicuramente illogico sostenere che il T. era presente al momento dell'omicidio - e non sarebbe arrivato dopo, come invece sostenuto dall'imputato (e anche questa negazione è stata valutata dal giudice di merito, e ovviamente in senso sfavorevole all'imputato) - in quanto sui suoi indumenti sono state trovate evidenti tracce di sangue della vittima [CSC_47502_2007] ${ }^{12}$

In example (1) ovviamente ('obviously') refers to the whole sentence, whereas sicuramente ('certainly') in the very first sentence only refers to illogico ('illogical') and therefore has not been considered as a sentence adverb. By using that adverb the judge is backing and approving the decision against the accused person adopted by his colleague of the lower court. The fact that the accused person declared that he arrived later and was not present during the mur-

\footnotetext{
12 'Certainly, it is not illogical to maintain that Mr. T. was present at the moment of the murder - he would not arrive later, as the accused person maintained (this negation as well has been evaluated by the lower-court judge, and obviously against the accused person) - since on his clothes evident blood traces of the victim were found' [translation for informative purposes].
} 
Gianluca Pontrandolfo: A corpus-based study of sentence adverbs in judicial language

der (while he was there at that time, as blood was found on his clothes) was "obviously" evaluated by the lower-court judge against him.

Example (2) is even more explicit as the adverb plainly is used more than once for stylistic purposes to express the evaluation of the court.

2. 64. As the Court of Appeal recognised, plainly there is a public interest in convicting those guilty of murder. Plainly too there is a public interest in maintaining the integrity of the criminal justice system. No less plainly, each interest is of a high order. Where, as here, these interests appear to conflict, how should that conflict be resolved? This is by no means an easy area of the law. Obviously, however, it is an important one. With that brief introduction let me at once turn to the facts, critical as ultimately these must be to the determination of this appeal. [SC_48_2010]

Also the final obviously is clearly used as a sentence adverb modifying the all sentence, in the same way as ciertamente ('certainly') is used in example (3).

3. Ciertamente una tal interpretación puede suponer un cierto reduccionismo sobre interpretaciones más acordes a la dimensión constitucional de la garantía o de la establecida en textos internacionales como la Convención europea sobre derechos. [TS_66_2011].13

\subsection{Evaluative}

Even though they are less frequent, evaluative sentence adverbs show interesting aspects of judicial discourse. First of all, they carry attitudinal stance, that is to say they are used to tell a speaker's or writer's attitude towards a proposition, which is why Garner (cf. $\S 1$ ) warns against its use in legal language as they "reveal the writer's own thoughts and biases".

Evaluation is generally conveyed in terms of "polarity": negative or positive (cf. GoźdźRoszkowski/Pontrandolfo 2013, 2014, Pontrandolfo/Goźdź-Roszkowski 2014) so that, quite often, there is a clear correlation between the evaluative stance conveyed by means of sentence adverbs and the outcome of judicial cases. Here, (con)textual information is essential to determine the scope of sentence adverbs since single sentences cannot reveal the whole picture which is clear only after reading the whole judgment.

4. Coerentemente è stato ritenuto credibile quanto riferito dalla minore all'insegnante [CSC_1821_2007] $]^{14}$

In (4) the adverb coerentemente ('consistently') is used to back the credibility of what has been stated by the minor in the judicial case.

5. To my mind it is logical that, by the same token that the defendant cannot require his after-acquired assets to be ignored in the determination of his present ability to pay, (as was expressly conceded by Mr Pownall both in his written case and in his oral argument although now rather surprisingly Lord Hope suggests an entirely different view of sec-

\footnotetext{
13 'Certainly, a similar interpretation may suppose a certain reductionism on interpretations more in line with the constitutional dimension of the guarantee or with the dimension established in international texts such as the European Convention on Human Rights.' [translation for informative purposes].

14 'Consistently, what the minor referred to the teacher may be considered credible' [translation for informative purposes].
} 
tion 17), nor should they be ignored in deciding whether he can pay an additional amount up to the point when he will "have disgorged an amount equivalent to all the benefit which has accrued to [him] from drug dealing" (per Rose LJ in Tivnan [1999] 1 Cr App R (S) 92, 97). [SC_5_2012]

In (5) surprisingly is used to criticise Lord Hope's change of mind, a clear evaluation that can be found quite frequently in English judgments, compared to Spanish or Italian judgments in which these clear evaluative remarks are more indirect, like in (6), where no explicit reference is made to the subject and object of the "obscure" (incomprensible) deduction (compared to the overt evaluation in the English text, (5)).

6. Más incomprensiblemente aún, la infracción constitucional vendría producida por aplicar tales preceptos a unos hechos elegidos por el recurrente, totalmente distintos a los declarados probados por la sentencia. Procede la desestimación del motivo. [TS_102_2012 $]^{15}$

\subsection{Domain}

Domain sentence adverbs reveal the viewpoint taken by the speaker or writer in discussing topics or the perspective from which one can look at the sentence. They are not very frequent in the corpus. Examples (7), (8) and (9) show how adverbs like formalmente ('formally'), (inter)nationally and jurisprudencialmente ('from the viewpoint of case law') are used in judicial discourse.

7. [...] dalle concordi ed univoche dichiarazioni rese da due dipendenti (G.M. e M.F.) i quali avevano affermato che, condicio sine qua non, per essere assunti era l'accettazione di condizioni di pagamento inferiori rispetto a quelle contrattuali sebbene, formalmente, tutto risultava in regola, [...] [CSC_4290_2012] ${ }^{16}$

8. Internationally, in 1992 the United Nations Committee, which monitors the Convention on the Elimination of all Forms of Discrimination against Women (CEDAW), adopted General Recommendation 19, which included in its definition of discrimination in relation to gender based violence "acts that inflict physical, mental or sexual harm or suffering, threats of such acts, coercion and other deprivations of liberty". [...] Nationally, in 1993 the House of Commons Home Affairs Committee in its Report on Domestic Violence adopted the definition "any form of physical, sexual or emotional abuse which takes place within the context of a close relationship" (Session 1992-93, Third Report, HC 245-I, para 5). [SC_3_2011]

9. Jurisprudencialmente se ha exigido en cualquier caso la constancia en el factum de alguna de las circunstancias indicadas en la norma, como la patente falta de intención de

\footnotetext{
15 'Even more incomprehensibly, the constitutional violation would be caused by the application of these precepts to some facts chosen by the recurrent, which are totally different from those that have been declared proved by the judgment. For this reason, the grounds shall be dismissed' [translation for informative purposes].

16 ' [...] from the unanimous and univocal declarations made by two employees (G.M. e M.F.) who had stated that, in order to be hired the condicio sine qua non was accepting a pay which was lower than that established in the contract, even though, formally, the situation was regular, [...]' [translation for informative purposes].
} 
Gianluca Pontrandolfo: A corpus-based study of sentence adverbs in judicial language

usar el arma con fines ilícitos (Cfr SSTS 19-5-92 , 4-7-94 , 27-4-98 , 20-12-01 ). [TS_930_2011].17

They do not play any evaluative role since they simply specify the perspective from which a statement is considered.

\subsection{Subject-oriented}

Subject-oriented sentence adverbs comment on the behaviour of the subject towards the action denoted by the sentence. They are among the most evaluative adverbials used in judicial language as they make explicit the judgment of the Court.

Here, the role of Supreme Courts become evident, as they are asked to judge the formal behavior of the lower-court judges and motivate their decisions. They can either agree with them thus confirming their judgment or disagree and uphold the decision of the lower-court judges (cf. Bowles 2002).

10. Giustamente il Tribunale ha desunto da tali conversazioni e dagli agguati tesi a G.V.V.e a C.A., cognato della ricorrente, l'esistenza dei due clan contrapposti operanti nella zona di (OMISSIS), ma non ha specificato da quali concreti elementi ha desunto che la ricorrente abbia agito con la consapevolezza di far parte dell'associazione [...] [CSC_4971_2010] ${ }^{18}$

In (10), for example, the Supreme Court judges agree with the lower court, as they have "correctly" (giustamente) inferred from some conversations the link between two criminal groups. The same applies to (11) in which the House of Lords' judges back the formal behaviour of the Tribunal.

11. 72 On 4 January 2001 it was common ground that the parties were not in a position to deal with matters then and sensibly and appropriately the judge adjourned the matter to the last date on which he would be sitting in January, namely 23 January. [HL_50_2005]

In (12) the adverb erróneamente ('wrongly') refers to an evaluative comment that the judges make of the plaintiff.

12. Lo que la parte recurrente hace en este motivo es cuestionar la calificación jurídica de los hechos enjuiciados, por entender -erróneamente- que no se puede condenar a este acusado porque la policía no observó que el mismo realizase transacción alguna con terceros en la vía pública, porque Jesús Luis negó en el juicio oral que fuese él quien llevase a cabo tales contactos, [...] [TS_176_2009] ${ }^{19}$

\footnotetext{
17 From the viewpoint of case law, the evidence in the factum of some of the circumstances indicated in the law, such as the clear unintentional use of the weapon for illicit purposes (see SSTS 19-5-92 , 4-7-94 , 27-4-98 , 20-12-01) was required in any case' [translation for informative purposes].

18 'Correctly, the Court has inferred from these conversations and from the ambushes made to G.V.V. and C.A., brother in law of the recurrent, the existence of two opposed clans operating in the area of (OMISSIS), but it has not specified from which concrete elements has inferred that the recurrent behaved with the awareness of being part of the association' [translation for informative purposes].

19 'What the recurrent does in these grounds is questioning the legal qualification of the judged facts, by understanding - wrongly - that the accused person cannot be sentenced because the police did not observe that he
} 
Subject-oriented adverbials also show that evaluative language is strictly related to politeness (Kurzon 2001) as well as polyphony and dialogism (Garzone 2016) in judicial discourse.

On the one hand, subject-oriented sentence adverbs may function as hedges with an important socio-cognitive role (Vass 2004). In (10), for example, the Supreme Court judges start their argumentation backing the line of reasoning of the lower-court judges ('rightly the courts have inferred the existence...'), but then criticise their vagueness ('they did not specify from which elements...'), which is a polite strategy used to hedge the criticism inherent in their comment.

On the other hand subject-oriented sentence adverbs are used as polyphonic/dialogic devices in legal argumentation (Garzone 2016: 2). As a matter of fact, many subject-oriented sentence adverbs express the various "voices", points of view, enunciative sources or instances that can be identified in judicial discourse (ibd.: 5). In (11) the House of Lords' judges are "talking" to the lower-court judges, which is a clear example of "manifest intertextuality". The same applies to (10) and (12), where the dialogic structure of the utterance is inevitably polyphonic.

\subsection{Speech-act}

Full-blown speech-act sentence adverbs are rare in the subcorpus, mainly because judges try to avoid personalysing their statements. The results refer to textual adverbs ${ }^{20}$, considered in the GGIC within the so-called "avverbi di atto linguistico", such as Più precisamente, preferisco non parlare ('More precisely, I'd prefer not to talk'), which can be paraphrased as Parlando più precisamente... ('Speaking more precisely').

13. Segnatamente, il Collegio ha osservato che già con delibera del 22.1.1996, la Giunta comunale aveva ricompreso l'intersezione teatro del sinistro nel centro abitato di (OMISSIS); [CSC_6405_2012] $]^{21}$

14. That is precisely how the Court of Appeal treated it in para 66. Having taken that factor into account, it still appeared to the Court that the interests of justice required it to order a retrial. [SC_48_2010]

15. Precisamente porque ese compromiso puede conferir a la intervención, cuando no la condición de coautoría, al menos la esencialidad y trascendencia de la cooperación necesaria. [TS_66_2011] $]^{22}$

carried out any transactions with third parties in the street, since Jesús Luis denied during the oral trial that he kept those contacts, [...]' [translation for informative purposes].

20 “Avverbi di atto linguistico come: francamente, personalmente, approssimativamente, per precisione, che qualificano la frase in quanto atto linguistico attribuendole una data caratteristica comunicativa; e avverbi espositivi (o testuali) come prima di tutto, infine, insomma, in una parola, etc." (2001: 388).

21 'Specifically, the Board has observed that already with the 22.1.1996 resolution, the local council had included again the intersection in which the fact took place in the town of (OMISSIS)' [translation for informative purposes].

22 'Precisely because that agreement may confer the intervention at least the essential and important traits of the necessary cooperation (if not the condition of co-authors)' [translation for informative purposes]. 
Gianluca Pontrandolfo: A corpus-based study of sentence adverbs in judicial language

\section{$5 \quad$ Discussion and final remarks}

Quantitatively sentence adverbs ending in -mente/-ly do not play a crucial role in conveying stance: the judges' attitude is conveyed mostly through adverbs of manner, as well as adjectives (Pontrandolfo/Goźdź-Roszkowski 2014). This is in line with Biber et al's findings in different registers (conversation, fiction, news, academic prose) (LGSWE 1999) and with De Cesare's (2018) results in online daily newspapers, who reached very similar results in a completely different genre.

As far as the three legal languages and cultures are concerned, there are some differences among them, most of them due to the different legal tradition (civil law vs. common law).

Subject-oriented sentence adverbs were expected to be found in higher percentage, due to the pivotal role of argumentation in judicial discourse (cf. Mazzi 2008, 2014, 2015), but their presence in the corpus is rather limited, especially in English (9\%) and Spanish (4\%) compared to Italian $(22 \%)$.

Evaluative/attitudinal sentence adverbs are indeed most frequent in English (24\%) compared to Italian $(17 \%)$ and Spanish (15\%), which is in line with the judge-made law vs civil-law tradition dichotomy.

Moreover, as signaled before, a high percentage of hapaxes (sentence adverbs occurring only once) has been found, with lexical variation being a common feature in the whole subcorpus.

The research that has been carried out cannot be considered as definite. A challenge for the future will be extending its scope to the wider category of adverbials (cf. De Cesare et al, forthcoming). Moreover, it will be interesting to study the semantic comparability of sentence adverbs in order to compare judicial reasoning across languages and legal cultures (civil law vs. common law). Finally, identifying evaluative phraseological patterns with which sentence adverbs tend to co-occur - that is to say, looking beyond the single sentence towards the whole (con)text - could be a revealing factor when it comes to defining the evaluative picture of how discourse is construed (Goźdź-Roszkowski/Hunston 2016) in judicial settings.

\section{References}

Anthony, Lawrence (2014): AntConc (Version 3.4.3). Tokyo: Waseda.

Baker, Paul/Hardie, Andrew/McEnery, Tony (2006): A glossary of corpus linguistics. Edinburgh: Edinburgh University Press.

De Cesare, Anna-Maria (2018): "Italian sentence adverbs in the left periphery: Modeling their functional properties in online daily newspapers”. In: Borreguero Zuloaga, Margarita et al. (eds.), Models of Discourse Units in Romance Languages [special issue of Revue Romane 53:1]: 96-120.

De Cesare, Anna-Maria/Albom, Ana/Cimmino, Doriana/Lupica Spagnolo, Marta (forthcoming): "Domain adverbials in the news. A corpus-based contrastive study of English, German, French, Italian and Spanish". Languages in Contrast.

Kurzon, Denis (2001): “The politeness of judges: American and English judicial behaviour". Journal of Pragmatics 33/1: 61-85.

Garner, Brian (2009): Garner's modern American usage. $3^{\text {rd }}$ ed. Oxford: Oxford University Press. 
Garzone, Giuliana (2016): "Polyphony and dialogism in legal discourse: Focus on syntactic negation". In: Tessuto, Girolamo et al. (eds.): Constructing legal discourses and social practices: Issues and perspectives. Cambridge, Cambridge Scholars Publishing: 2-27.

Goźdź-Roszkowski, Stanislaw/Pontrandolfo, Gianluca (2013): "Evaluative patterns in judicial discourse: A corpus-based phraseological perspective on American and Italian criminal judgments". International Journal of Law, Language and Discourse 3/2: 9-69.

Goźdź-Roszkowski, Stanislaw/Pontrandolfo, Gianluca (2014): "Facing the facts: Evaluative patterns in English and Italian judicial language”. In: Bhatia, Vijay K et al. (eds.): Language and law in professional discourse: Issues and perspectives. Newcastle upon Tyne, Cambridge Scholars Publishing: 10-28.

Goźdź-Roszkowski, Stanislaw/Hunston, Susan (eds.) (2016): Corpus Approaches to Evaluation (Special issue). Corpora 11/2.

Landone, Elena (2013a): «La modalidad liminar en la normativa territorial de las CCAA españolas». Cuadernos AISPI 2: 59-74.

Landone, Elena (2013b): «El adverbio en -mente en el español jurídico-administrativo: Lingüística de corpus y pragmática». In: Chierichetti, Luisa/Garofalo, Giovanni (eds.): Discurso profesional y lingüística de corpus. Perspectivas de investigación. Bergamo, CELSB: $101-124$.

Mazzi, Davide (2008): "'I first have to decide whether there were any notes in the first place. I consider that there probably were': Adverbials of stance in equity judges' argumentation". Textus 21: 505-522.

Mazzi, Davide (2014): “'Our reading would lead to...': Corpus perspectives on pragmatic argumentation in US Supreme Court judgments”. Journal of Argumentation in Context 3: 103-125.

Mazzi, Davide (2015): “'It must be obvious that this line of argument is utterly inconsistent...': On attitudinal qualification in English judicial discourse across legal systems". Bulletin Suisse de Linguistique Appliquée: 51-67.

Partington, Alan/Duguid, Alison/Taylor, Charlotte (2013): Patterns and meanings in discourse: Theory and practice in corpus-assisted discourse studies (CADS). Amsterdam/Philadelphia: Benjamins.

Pontrandolfo, Gianluca (2016): Fraseología y lenguaje judicial. Las sentencias penales desde una perspectiva contrastiva. Roma: Aracne.

Pontrandolfo, Gianluca/Goźdź-Roszkowski, Stanislaw (2014): "Exploring the local grammar of evaluation: The case of adjectival patterns in judicial discourse". Research in Language 12/1: 71-91.

Ramat, Paolo/Ricca, Davide (1998): "Sentence adverbs in the languages of Europe". In: Auwera, Johan van der/Ó Baoill, Dónall (eds.): Adverbial constructions in the languages of Europe. Berlin/New York, Mouton de Gruyter: 187-275.

Rovere, Giovanni (2000): «L'avverbiale strumentale nel linguaggio giuridico». In: Schena, Leandro/Snel-Trampus, Rita (eds.): Traduttori e giuristi a confronto. Bologna, CLUEB: $25-35$.

Salzwedel (2012): Scrubbing Adverbs From Legal Writing. https://lawyerist.com/47561/scrubbing-adverbs-from-legal-writing/ [last accessed on 08/10/2018] 
Gianluca Pontrandolfo: A corpus-based study of sentence adverbs in judicial language

Salzwedel (2013): The Pitfalls of Sentence Adverbs in Legal Writing. https://lawyerist.com/56658/the-pitfalls-of-sentence-adverbs-in-legal-writing/__ [last accessed on $08 / 10 / 2018]$

Solan, Lawrence M. (1993): The language of judges. Chicago: Chicago University Press.

Scott, Mike (2008): WordSmith Tools 5.0. Stroud: Lexical Analysis Software.Vass, Holly (2004): "Socio-cognitive aspects of hedging in two legal discourse genres". Ibérica 7/2004: 125-141.

\section{Grammar handbooks}

IT)

GGIC: Renzi, Lorenzo/Salvi, Giampaolo/Cardinaletti, Anna (eds.) (2001) Grande grammatica italiana di consultazione (3 vol.), Bologna: Il Mulino.

$\mathrm{EN})$

LGSWE: Biber, Douglas/ Johansson, Stig/ Leech, Geoffrey/ Conrad, Susan (eds.) (1999) Longman Grammar of Spoken and Written English, London: Longman.

ES)

GDLE: Bosque, Ignacio/ Demonte, Verónica (eds.) (1999) Gramática Descriptiva de la Lengua Española (3 vol), Madrid: Espasa.

GREIT: San Vicente, Félix (ed.) (2013) Gramática de Referencia de Español para Italófonos (3 vol.), Bologna: Clueb. 